\title{
ОСОБЛИВОСТІ ПОЄДНАНОГО ПЕРЕБІГУ ХРОНІЧНОГО ОБСТРУКТИВНОГО ЗАХВОРЮВАННЯ ЛЕГЕНЬ ТА ГІПЕРТОНІЧНОЇ ХВОРОБИ
}

\author{
ДВНЗ «Тернопільський державний медичний університет \\ імені І.Я. Горбачевського МОЗ України», м. Тернопіль, Україна
}

\begin{abstract}
Мета: проаналізувати особливості поєднаного перебігу хронічного обструктивного захворювання легень II стадії та гіпертонічної хвороби (ГХ) II стадії в гендерному аспекті.

Матеріали і методи. Ретроспективно проаналізовано 420 історій хвороб пацієнтів, які перебували на стаціонарному лікуванні у пульмонологічному відділенні Тернопільської університетської лікарні 3 діагнозом «хронічне обструктивне захворювання легень» (ХОЗЛ) протягом 2014 і 2016 рр.

Результати. Серед пацієнтів із хронічним обструктивним захворюванням легень переважали особи чоловічої статі (65,95 \%). Поділ за статтю пацієнтів із ХОЗЛ ІІ стадії виглядає таким чином: чоловіки - 59,86 \%, жінки - 40,14 \%.

Висновки. Серед пацієнтів із ХОЗЛ II стадії 28,67 \% хворих не мали супутньої патології, 27,27 \% - перебіг основного захворювання поєднувався з гіпертонічною хворобою II стадії, 43,36 \% - ХОЗЛ поєднувалося з іншими захворюваннями. Аналіз отриманих даних за гендерною ознакою вказує на переважання у пацієнтів чоловічої статі коморбідності ХОЗЛ з іншими патологіями, причому найчастіше (у 33 \% хворих) із гіпертонічною хворобою. В осіб жіночої статі, хворих на ХОЗЛ, окрім гіпертонічної хвороби, з високою частотою спостерігалась ішемічна хвороба серця й захворювання ендокринної системи.
\end{abstract}

КЛЮЧОВІ СЛОВА: хронічне обструктивне захворювання легень; гіпертонічна хвороба; стать.

Хронічні обструктивні захворювання легень (ХОЗЛ) набувають щораз більшого медико-соціального значення, оскільки за прогнозами Всесвітньої організації охорони здоров'я (ВООЗ), до 2020 р. дане захворювання займатиме 3 місце у світі в структурі смертності та 5 - у структурі непрацездатності [4, 9, 20, 21, 23]. Це призведе до значних економічних витрат як для хворого, так і для суспільства у цілому.

Одним із визначальних фракторів прогнозу при ХОЗЛ $є$ наявність системних проявів захворювання та коморбідних станів. За даними наукових джерел, провідною причиною смерті хворих на ХОЗЛ є розвиток серцево-судинних розладів $[10,12]$. Причиною частої асоціації ХОЗЛ і серцево-судинних захворювань (СС3) може бути загальний фрактор ризику куріння [1, 2], а також персистуюче системне запалення, хронічні інфекції, приймання деяких лікарських засобів, що підвищують симпатичну активність нервової системи [27]. На даний час спостерігають наукові дані про те, що хронічне персистуюче системне запалення, наявне при ХОЗЛ, впливає на патогенез атеросклерозу і ССЗ у хворих на ХОЗЛ.

Виявилося, що пацієнти з ХОЗЛ мають в 2-3 рази більший кардіоваскулярний ризик [22, 24], при цьому гіпертонічна хвороба відіграє безпосередню роль. За результатами численних досліджень встановлено, що серцево-судинна захворюваність і смертність у пацієнтів із ХОЗЛ практично в 2 рази вища, порівняно із загальною популяцією $[14,16]$. Разом $з$ тим встановлено, що більше ніж 50 \% хворих на ХОЗЛ мають артеріальну гіпертензію [12].

На сьогодні взаємозв'язок між ХОЗЛ та супутніми захворюваннями має декілька пояснень. 3 одного боку, системне запалення в легенях, яке характерне для ХОЗЛ, зумовлює розвиток коморбідної патології. На думку інших авторів, хОЗЛ є одним із проявів системного запального стану 3 мультиорганним ураженням [5, 15, 25]. Це означає, що дослідження біохімічних процесів, патогенетичних механізмів, клінічних проявів ХОЗЛ повинно охоплювати не лише легені, але й організм у цілому [5].

Мета дослідження: проаналізувати особливості поєднаного перебігу ХОЗЛ II стадії та ГX II стадії в гендерному та віковому аспектах.

Матеріали і методи. Ретроспективно проаналізовано 420 історій хвороб пацієнтів, які перебували на стаціонарному лікуванні у пульмонологічному відділенні Тернопільської університетської лікарні з діагнозом «хронічне обструктивне захворювання легень» протягом 2014 і 2016 рр.

Оцінку історій хвороб проводили шляхом вивчення паспортних та анамнестичних даних, об'єктивного обстеження, лабораторних та інструментальних методів досліджень. Статистичну об- 
робку проводили за допомогою програм «Microsoft Excel» та «Statistica for Windows».

Результати дослідження та їх обговорення. Протягом багатьох років ХОЗЛ вважали захворюванням переважно людей літнього віку чоловічої статі, проте останнім часом зростає як кількість жінок, так і кількість осіб працездатного віку, які

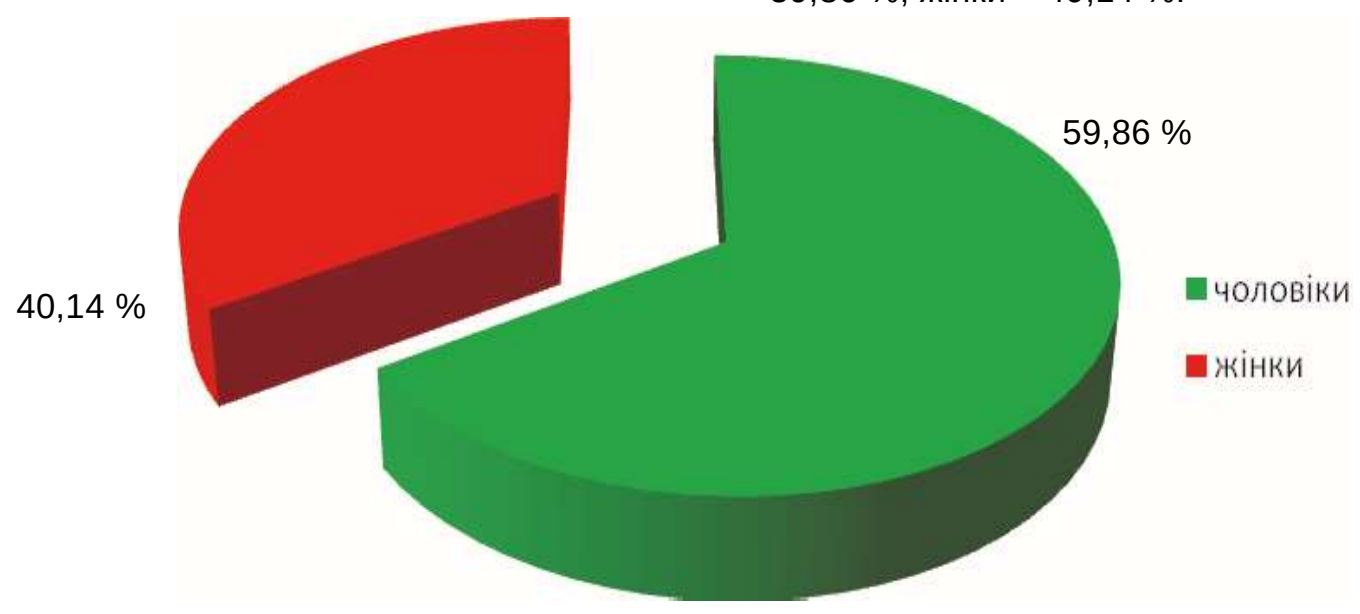

хворіють на ХОЗЛ. Результати дослідження вказують на те, що серед пацієнтів, хворих на ХОЗЛ, переважали особи чоловічої статі (65,95 \%) (рис. 1). Якщо брати до уваги лише карти історій хвороб пацієнтів із ХОЗЛ ІІ стадії (142 особи, об'єм фрор-

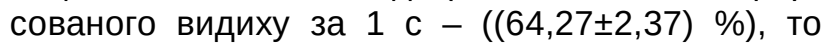
поділ за статтю виглядає таким чином: чоловіки $59,86 \%$, жінки - 40,14\%.

Puc. 1. Поділ пацієнтів, хворих на ХОзЛ за статтю.

Отже, результати дослідження вказують на переважання кількості чоловіків у структурі захворюваності на ХОЗЛ, що дещо відрізняється від тенденцій у світі. Так, значна кількість досліджень у США говорить про зменшення частоти госпіталізацій чоловіків із приводу загострень ХОЗЛ та їх смертності, тоді як смертність серед жінок залишається високою [11, 20, 21]. Відмінність результатів, на нашу думку, пов'язана із низьким відсотком осіб жіночої статі в Тернопільській області, які курять. Варто зазначити, що згідно з даними Державного комітету статистики України, поширеність куріння серед дорослих чоловіків у 2011 р. становила $46 \%$, серед дорослих жінок - 6 \%, у цілому - $24 \%$ [3]. Найбільшою проблемою українських жінок $€$ пасивне куріння, що пояснює досить великий їх відсоток у структурі ХОЗЛ.

Порівнюючи вік хворих на ХОЗЛ ІІ стадії різної статі варто зазначити, що в чоловіків він становив $(48,16 \pm 1,47)$ року і практично не відрізнявся від показника у жінок $(52,32 \pm 1,84)$ року. Отримані дані свідчать про переважно працездатний вік пацієнтів із ХОЗЛ, що зумовлює економічні втрати держави.

Враховуючи високу коморбідність ХОЗЛ і гіпертонічної хвороби, що поглиблює перебіг обох патологій, було проаналізовано основні статистичні дані 3 карт історій хвороб пацієнтів із ХОЗЛ без супутньої патології і з поєднаним перебігом ХОЗЛ II стадії і ГX ІІ стадії. Встановлено, що серед 142 пацієнтів із ХОЗЛ ІІ стадії 28,67 \% хворих не мали супутньої патології, 27,27 \% - перебіг основного захворювання поєднувався з ГХ ІІ стадії, 43,36 \% ХОЗЛ поєднувалося 3 іншими захворюваннями.
Аналіз отриманих даних за гендерною ознакою вказує на переважання у пацієнтів чоловічої статі коморбідності ХОЗЛ з іншими патологіями, причому найчастіше (у 33 \% хворих) воно поєднувалося з ГХ. В осіб жіночої статі, хворих на ХОЗЛ, окрім ГX, 3 високою частотою спостерігали ішемічну хворобу серця й захворювання ендокринної системи (рис. 2). Отримані дані співпадають з результатами інших дослідників. Так, Csaba Farsang та співавт. зазначають, що найчастішими коморбідними патологіями при ХОЗЛ є ГХ (28\%), цукровий діабет (14 \%) й ішемічна хвороба серця (10\%) [29].

Проведений аналіз показників основних груп пацієнтів із ХОЗЛ ІІ стадії показав, що вік хворих при супутній ГХ був достовірно вищий в осіб обох статей, стосовно монопатології, при цьому у жінок він був більшим на 14,39 \%, ніж у чоловіків (табл. 1). Маса хворих із коморбідністю ХОЗЛ II стадії і ГXII стадії була достовірно вища в осіб обох статей, стосовно ХОЗЛ без супутніх патологій. Аналіз літературних джерел свідчить про те, що пацієнти 3 ХОЗЛ й низьким індексом маси тіла мають високий ризик бронхообструкцій, остеопорозу, аневризми черевної аорти, периферійних судинних захворювань, зловживань психоактивними речовинами $[8,18] .3$ іншого боку, у людей з ХОЗЛ і високим індексом маси тіла менший ризик бронхообструкцій й остеопорозу, проте виявлено цілий ряд супутніх захворювань та фракторів ризику розвитку серцево-судинних захворювань з підвищеним системним запаленням [17, 19, 26, 28, 30]. M. J. Divo та співавт. вважають, що жирова тканина відіграє модулюючу роль у розвитку і прогресуванні 
чоловіки

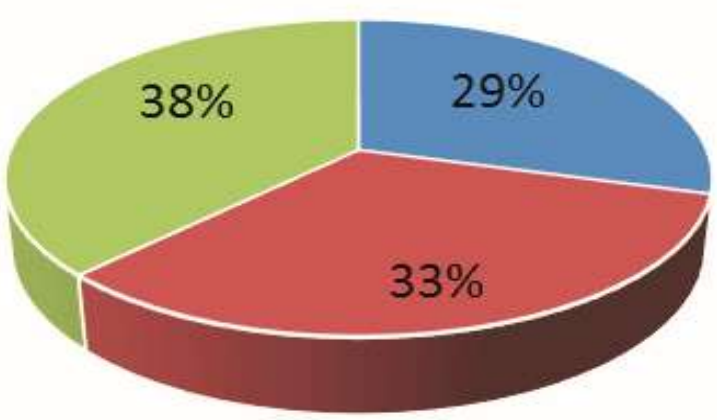

жінки

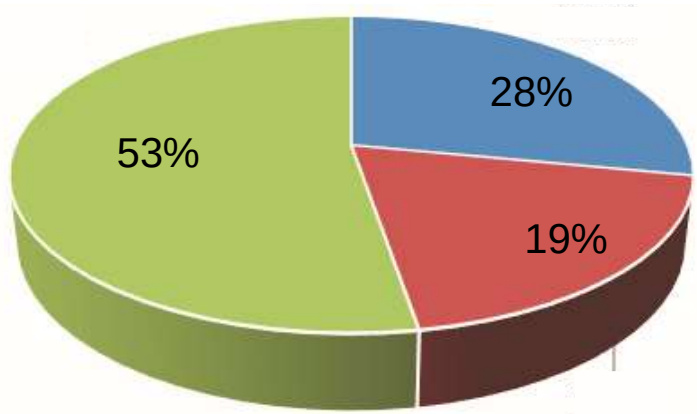

- хозл без супутньої патології

- хозЛі гх

" ХОЗЛ з іншою коморбідною патологією

Puc. 2. Гендерний поділ коморбідності ХОЗл II стадії з іншими патологіями.

Таблиця 1. Характеристика пацієнтів із хронічним обструктивним захворюванням легень залежно від статі

\begin{tabular}{|c|c|c|c|c|}
\hline \multirow{2}{*}{ Показник } & \multicolumn{2}{|c|}{$\begin{array}{c}\text { Пацієнти з ХОЗл ІІ стадії̈ без супутньої } \\
\text { патології }\end{array}$} & \multicolumn{2}{|c|}{$\begin{array}{c}\text { Пацієнти } 3 \text { ХОЗЛ II стадії і } \\
\text { ГХ ІІ стадії }\end{array}$} \\
\hline & чоловіки $(n=25)$ & жінки $(\mathrm{n}=16)$ & чоловіки $(n=28)$ & жінки $(\mathrm{n}=11)$ \\
\hline Вік, роки & $45,96 \pm 2,50$ & $43,44 \pm 3,38$ & $55,39 \pm 1,97^{\star}$ & $63,36 \pm 3,64^{\star *} \#$ \\
\hline Мaca, кг & $80,48 \pm 2,82$ & $65,27 \pm 2,41 \#$ & $94,54 \pm 3,29^{*}$ & $83,82 \pm 6,01^{*}$ \\
\hline Зріст, см & $173,68 \pm 1,34$ & $162,73 \pm 0,99 \#$ & $169,19 \pm 6,03$ & $161,91 \pm 1,45$ \\
\hline ЧСС, уд./Хв & $76,68 \pm 2,34$ & $80,13 \pm 1,51$ & $81,21 \pm 2,26$ & $83,82 \pm 2,25$ \\
\hline СAT, мм рт. ст. & $131,60 \pm 2,23$ & $132,19 \pm 2,23$ & $147,32 \pm 2,65^{*}$ & $145,45 \pm 2,47^{*}$ \\
\hline ДАТ, мм рт. ст. & $82,80 \pm 1,50$ & $81,56 \pm 1,49$ & $91,79 \pm 1,71^{*}$ & $90,91 \pm 2,60^{*}$ \\
\hline $\begin{array}{l}\text { ЧД, кількість дихальних } \\
\text { рухів за хвилину }\end{array}$ & $21,56 \pm 0,38$ & $21,06 \pm 0,42$ & $21,68 \pm 0,26$ & $21,36 \pm 0,36$ \\
\hline $\begin{array}{l}\text { Тривалість } \\
\text { захворювання, роки }\end{array}$ & $5,13 \pm 0,98$ & $5,86 \pm 1,85$ & $11,68 \pm 1,38^{\star}$ & $6,91 \pm 1,34 \#$ \\
\hline
\end{tabular}

Примітки: * - вірогідність достовірна між пацієнтами з ХОЗЛ ІІ стадії однієї статі; \# - вірогідність достовірна між пацієнтами з ХОЗЛ ІІ стадії різної статі.

серцево-судинних хвороб у пацієнтів із хОзЛ [13]. Проведені багаточисленні дослідження показали, що пацієнти з надмірною масою тіла та ожирінням 3 ХОзЛ мають менший ризик смертності від усіх причин $[6,7]$. Це явище відоме як «парадокс ожиріння», який визначається як зворотний зв'язок між виживанням та ожирінням та спостерігався при різних хронічних захворюваннях.

Встановлено, що середня тривалість захворювання коливалася в межах 5-6 років у пацієнтів обох статей з ХОЗЛ без супутніх патологій. В осіб жіночої статі тривалість захворювань не залежала від статі і коморбідності. У чоловіків із поєднаним перебігом ХОзЛ ІІ стадії і ГX ІІ стадії тривалість захворювання практично вдвічі перевищувала показники інших груп. Отримані дані не мають єдиного пояснення і потребують детальнішого аналізу.

\section{Висновки}

1. Ретроспективний аналіз історій хвороб свідчить про те, що серед пацієнтів, хворих на ХОЗЛ, переважають особи чоловічої статі (65,95\%). Кількість жінок 3 ІІ стадією ХОЗл була на 19,72 \% меншою, ніж у чоловіків. Серед пацієнтів із ХОЗл II стадії 28,67 \% хворих не мали супутньої патології, $27,27 \%$ - перебіг основного захворювання поєднувався з гіпертонічною хворобою II стадії, 43,36 \% - ХОЗЛ поєднувалося з іншими захворюваннями.

2. Аналіз отриманих даних за гендерною ознакою вказує на переважання у пацієнтів чоловічої статі коморбідності ХОЗЛ з іншими патологіями, причому найчастіше (у 33 \% хворих) із гіпертонічною хворобою. В осіб жіночої статі, хворих на ХОЗЛ, окрім гіпертонічної хвороби, з високою частотою спостерігали ішемічну хворобу серця й захворювання ендокринної системи.

Перспективи подальших досліджень передбачають вивчення ролі генетичних маркерів у розвитку гіпертонічної хвороби у пацієнтів із ХОЗЛ. 


\section{Список літератури}

1. Ивановский М. О. Изменение характеристик микрососудистого кровотока в тканях пародонта под влиянием курения / М. О. Ивановский, Т. Н. Юшманова // Экология человека. - 2008. - № 3. - С. 23-28.

2. Орехова Л. Ю. Состояние тканей пародонта у курящих пациентов с хронической обструктивной болезнью легких /

л. Ю. Орехова, Н. Л. Шапорова, Е. В. Косова // Пародонтология. - 2008. - № 1. - С. 12-17.

3. Скорочення поширеності куріння в Україні призвело до скорочення числа викликаних тютюном хвороб та смертей [Електронний ресурс] // Прес-служба МОЗ України. - 2012. - Режим доступу : http://www.moz.gov.ua/ua/portal/ pre_20120403_1.html

4. Anxiety and depression in patients with chronic obstructive pulmonary disease (COPD) / R. L. Mikkelsen, T. Middelboe, C. Pisinger [et al.] // A review. Nord J. Psychiatry. - 2004. - Vol. 58. - P. 65-70.

5. Barnes P. J. Systemic manifestations and comorbidities of COPD / P. J. Barnes, B. R. Celli // Eur. Respir. J. - 2009. No. 33. - P. 1165-1185.

6. Body mass index and mortality in chronic obstructive pulmonary disease: a meta-analysis / C. Cao, R. Wang, J. M. Wang [et al.] // PloS One. - 2012. - P. 7-8.

7. Body mass index and mortality in chronic obstructive pulmonary disease: A dose-response meta-analysis / Y. Guo, T. Zhang, Z. Wang [et al.] // Medicine. - 2016. - No. 95 (28). - P. e4225.

8. Bonfield T. L. Adult mesenchymal stem cells: an innovative therapeutic for lung diseases / T. L. Bonfield, A. I. Caplan // Discov. Med. - 2010. - № 9 (47). - P. 337-345.

9. Brown C. A. Failure of cigarette smoking to explain international differences in mortality from chronic obstructive pulmonary disease / C. A. Brown, I. K. Crombie, H. Tunstall-Pedoe // Epidemiol. Community Health. - 1994. - No. 48. - P. $134-139$.

10. Cardiac disease in chronic obstructive pulmonary disease / J. A. Falk, S. Kadiev, G. J. Criner [et al.] // Proc. Am. Thorac. Soc. - 2008. - Vol. 5. - P. 543-548.

11. Chronic obstructive pulmonary disease surveillance - United States, 1971-2000 / D. M. Mannino, D. M. Homa, L. J. Akinbami [et al.] // Morbidity and Mortality Weekly Report Surveillance Summaries. - 2002. - Vol. 51. - P. 1-18.

12. Comorbidities and risk of mortality in patients with chronic obstructive pulmonary disease / M. Divo, C. Cote, J.P. Torres [et al.] // Am. J. Respir. Crit. Care. Med. - 2012. - Vol. 186. - P. 155-161.

13. Comorbidity distribution, clinical expression and survival in COPD patients with different body mass index / M. J. Divo, C. Cabrera, C. Casanova [et al.] // J.COPD F. - 2014. - No. 1 (2). - P. 229-238.

14. COPD and incident cardiovascular disease hospitalizations and mortality: Kaiser Permanente Medical Care Program / S. Sidney, M. Sorel, C. P. Quesenberry [et al.] // Chest. - 2005. - Vol. 128. - P. 2068-2075.

15. Fabbri L. M. From COPD to chronic systemic inflammatory syndrome? / L. M. Fabbri, K. F. Rabe // Lancet. - 2007. No. 370. - P. 797-799.

16. Huiart L. Cardiovascular morbidity and mortality in COPD / L. Huiart, P. Ernst, S. Suissa // Chest. - 2005. - Vol. 128. P. 2640-2646.

17. Kern E. Metabolic syndrome and systemic inflammation in COPD / E. Kern // COPD. - 2011. - No. 8 (6). - P. 395-396.

18. Lungs, bone marrow, and adipose tissue. A network approach to the pathobiology of chronic obstructive pulmonary disease / A. Agustí, J. A. Barberà, E. F. M. Wouters [et al.] // Am. J. Respir. Crit. Care Med. - 2013. - No. 188 (12). P. 1396-1406.

19. Metabolic syndrome as a precursor of cardiovascular disease and type 2 diabetes mellitus / R. B. D'Agostino, H. Parise, L. Sullivan, J. B. Meigs // Circulation. - 2005. - No. 112 (20). - P. 3066-3372.

20. Michaud C. M. Burden of disease - implications for future research / C. M. Michaud, C. J. Murray, B. R. Bloom // JAMA. 2001. - Vol. 285. - P.535- 539.

21. Miniño A. M. Deaths: Preliminary data for 2008 / A. M. Miniño, J. Q. Xu, K. D. Kochanek // National Vital Statistics Report. 2010. - Vol. 59. - P. 2-8.

22. Mortality in COPD: Role of comorbidities / D. D. Sin, N. R. Anthonisen, J. B. Soriano [et al.] // Eur. Respir. J. - 2006. Vol. 28 (6). - P. 1245-1257.

23. Murray C.J. Alternative projections of mortality and disability by cause 1990-2020: Global Burden of Disease Study I C. J. Murray, A. Lopez // Lancet. - 1997. - Vol. 349. - P.1498-1504.

24. Rubinsztajn R. Mortality and comorbidity in hospitalized chronic obstructive pulmonary disease patients / R. Rubinsztajn, R. Chazan // Pneumonol. Alergol. Pol. - 2011. - Vol. 79 (5). - P. 343-346.

25. Sevenoaks M. J. Chronic obstructive pulmonary disease, inflammation and co-morbidity - a common inflammatory phenotype? / M. J. Sevenoaks, R. A. Stockley // Respiratory Research. - 2006. - No. 7. - P. 70.

26. The body-mass index, airflow obstruction, dyspnea, and exercise capacity index in chronic obstructive pulmonary disease / B. R. Celli, C. G. Cote, J. M. Marin [et al.] // N. Engl. J. Med. - 2004. No. 350 (10). - P. 1005-1012.

27. The effects of combination treatment with a long-acting beta2-agonist and a corticosteroid on salivary flow rate, secretory immunoglobulin A, and oral health in children and adolescents with moderate asthma: a 1-month, single-blind clinical study / C. Sag, F. O. Ozden, G. Acikgoz, F. Y. Anlar // Clin. Ther. - 2007. - № 29. - P. 2236-2242.

28. Tiengo A. The metabolic syndrome, diabetes and lung dysfunction / A. Tiengo, G. P. Fadini, A. Avogaro // Diabetes Metab. J. - 2008. - No. 34 (5). - P. 447-454.

29. Treatment of Hypertension in Patients with Chronic Obstructive Pulmonary Disease (COPD) / Csaba Farsang, Istvan Kiss, Andrzej Tykarski, Krzysztof Narkiewicz // Journal fur Hypertonie. - 2013. - No. 17 (4). - P. 163-165.

30. Weight loss is a reversible factor in the prognosis of chronic obstructive pulmonary disease / A. M. Schols, J. Slangen, L. Volovics, E. F. Wouters // Am. J. Respir. Crit. Care Med. - 1998. - No. 157 (6 Pt 1). - P. 1791-1797. 


\section{References}

1. Ivanovskiy, M.O., \& Yushmanova, T.N. (2008). Izmenenie kharakteristik mikrososudistogo krovotoka v tkanyah parodonta pod vliyaniem kureniya [Changes in the characteristics of microvascular blood flow in periodontal tissues under the influence of smoking]. Ekologiya cheloveka - Human Ecology, 3, 23-28 [in Russian].

2. Orekhova, L.Yu., Shaporova, N.L., \& Kosova, E.V. (2008). Sostoyanie tkaney parodonta u kuryaschikh patsientov s khronicheskoy obstruktivnoy boleznyu legkikh [Condition of periodontal tissues in smokers with chronic obstructive pulmonary disease]. Parodontologiya - Periodontology, 1, 12-17 [in Russian].

3. Skorochennia poshyrenosti kurinnia v Ukraini pryzvelo do skorochennia chysla vyklykanykh tiutiunom khvorob ta smertei. Pres-sluzhba MOZ Ukrainy [Reducing the prevalence of smoking in Ukraine has led to a reduction in the number of tobacco-related illnesses and deaths. Press service of the Ministry of Health of Ukraine]. (2012). www.moz.gov.ua. Retrieved from http://www.moz.gov.ua/ua/portal/pre_20120403_1.html [in Ukrainian].

4. Mikkelsen, R.L., Middelboe, T., \& Pisinger, C. (2004). Anxiety and depression in patients with chronic obstructive pulmonary disease (COPD). Nord J. Psychiatry, 58, 65-70.

5. Barnes, P.J., \& Celli, B.R. (2009). Systemic manifestations and comorbidities of COPD. Eur. Respir. J., 33, 1165-1185.

6. Cao, C., Wang, R., Wang, \& J.M. (2012). Body mass index and mortality in chronic obstructive pulmonary disease: a meta-analysis. PloS One, 7, 8.

7. Guo, Y., Zhang, T., Wang, Z., Yu, F., Xu, Q., Guo, W., ... He, J. (2016). Body mass index and mortality in chronic obstructive pulmonary disease: A dose-response meta-analysis. Medicine, 95 (28), e4225.

8. Bonfield, T.L., \& Caplan, A.I. (2010). Adult mesenchymal stem cells: an innovative therapeutic for lung diseases. Discov. Med., 9 (47), 337-345.

9. Brown, C.A., Crombie, I.K., \& Tunstall-Pedoe, H. (1994). Failure of cigarette smoking to explain international differences in mortality from chronic obstructive pulmonary disease. Epidemiology Community Health, 48, 134-139.

10. Falk, J.A., Kadiev, S., \& Criner, G.J. (2008). Cardiac disease in chronic obstructive pulmonary disease. Proc. Am. Thorac. Soc., 5, 543-548.

11. Mannino, D.M. Homa, D.M., \& Akinbami, L.J. (2002). Chronic obstructive pulmonary disease surveillance - United States, 1971-2000. Morbidity and Mortality Weekly Report Surveillance Summaries, 51, 1-18.

12. Divo, M., Cote, C., \& Torres, J.P. (2012). Comorbidities and risk of mortality in patients with chronic obstructive pulmonary disease. Am. J. Respir. Crit. Care Med., 186, 155-161.

13. Divo, M.J., Cabrera, C., \& Casanova, C. (2014). Comorbidity distribution, clinical expression and survival in COPD patients with different body mass index. J. COPD F, 1 (2), 229-238.

14. Sidney, S., Sorel, M., \& Quesenberry, C.P. (2005). COPD and incident cardiovascular disease hospitalizations and mortality: Kaiser Permanente Medical Care Program. Chest, 128, 2068-2075.

15. Fabbri, L.M., \& Rabe, K.F. (2007). From COPD to chronic systemic inflammatory syndrome? Lancet, 370, 797-799.

16. Huiart, L., Ernst, P., \& Suissa, S. (2005). Cardiovascular morbidity and mortality in COPD. Chest, 128, 2640-2646

17. Kern, E. (2011). Metabolic syndrome and systemic inflammation in COPD. COPD, 8 (6), 395-396.

18. Agustí, A., Barberà, J.A., Wouters, E.F.M., Peinado, V.I., \& Jeffery, P.K. (2013). Lungs, bone marrow, and adipose tissue. A network approach to the pathobiology of chronic obstructive pulmonary disease. Am. J. Respi.r Crit. Care Med., 188 (12), 1396-1406.

19. D'Agostino, R.B., Parise, H., Sullivan, L., \& Meigs, J.B. (2005). Metabolic syndrome as a precursor of cardiovascular disease and type 2 diabetes mellitus. Circulation, 112 (20), 3066-3372.

20. Michaud, C.M., Murray, C.J., \& Bloom, B.R. (2001). Burden of disease - implications for future research. JAMA, 285, 535-539.

21. Miniño, A.M., Xu, J.Q., \& Kochanek, K.D. (2010). Deaths: Preliminary data for 2008. National Vital Statistics Reports, $59,2-8$. 22. Sin, D.D., Anthonisen, N.R., Soriano, J.B., et al. (2006). Mortality in COPD: Role of comorbidities. Eur. Respi.r J., 28 (6), 1245-1257.

23. Murray, C.J., \& Lopez, A. (1997). Alternative projections of mortality and disability by cause 1990-2020: Global Burden of Disease Study. Lancet, 349, 1498-1504.

24. Rubinsztajn, R., \& Chazan, R. (2011). Mortality and comorbidity in hospitalized chronic obstructive pulmonary disease patients. Pneumonol. Alergo.I Pol., 79 (5), 343-346.

25. Sevenoaks, M.J., \& Stockley, R.A. (2006). Chronic obstructive pulmonary disease, inflammation and co-morbidity - a common inflammatory phenotype? Respiratory Research, 7, 70.

26. Celli, B.R., Cote, C.G., \& Marin, J.M. (2004). The body-mass index, airflow obstruction, dyspnea, and exercise capacity index in chronic obstructive pulmonary disease. N. Engl. J. Med., 350 (10), 1005-1012.

27. Sag, C., Ozden, F.O., Acikgoz, G., \& Anlar, F.Y. (2007). The effects of combination treatment with a long-acting beta2agonist and a corticosteroid on salivary flow rate, secretory immunoglobulin $A$, and oral health in children and adolescents with moderate asthma: a 1-month, single-blind clinical study. Clin. Ther., 29, 2236-2242.

28. Tiengo, A., Fadini, G.P., \& Avogaro, A. (2008). The metabolic syndrome, diabetes and lung dysfunction. Diabetes Metab. J., 34 (5), 447-454.

29. Farsang, C., Kiss, I., Tykarski, A., Narkiewicz, K. (2013). Treatment of hypertension in patients with chronic obstructive pulmonary disease (COPD). Journal fur Hypertonie, 17 (4), 163-165.

30. Schols, A.M., Slangen, J., Volovics, L., \& Wouters, E.F. (1998). Weight loss is a reversible factor in the prognosis of chronic obstructive pulmonary disease. Am. J. Respir. Crit. Care Med., 157 (6 Pt 1), 1791-1797. 
ОСОБЕННОСТИ СОЧЕТАННОГО ТЕЧЕНИЯ ХРОНИЧЕСКОГО ОБСТРУКТИВНОГО ЗАБОЛЕВАНИЯ ЛЕГКИХ И ГИПЕРТОНИЧЕСКОЙ БОЛЕЗНИ

К.Я. Максив, И.В. Пирус, Р.Р. Осинчук, Г.Г. Габор, И.Я. Криницкая, М.И. Марущак

ГВУз «Тернопольский государственный медицинский университет имени И.Я. Горбачевского МЗ Украины»,

г. Тернополь, Украина

Цель: проанализировать особенности сочетанного течения хронического обструктивного заболевания легких II стадии и гипертонической болезни (ГБ) II стадии в гендерном аспекте.

Материалы и методы. Ретроспективно проанализированы 420 историй болезней пациентов, находившихся на стационарном лечении в пульмонологическом отделении Тернопольской университетской больницы с диагнозом «хроническое обструктивное заболевание легких» (ХОЗЛ) на протяжении 2014 и 2016 гг.

Результаты. Среди пациентов с хроническим обструктивным заболеванием легких преобладали лица мужского пола (65,95 \%). Гендерное распределение пациентов с ХОЗЛ II стадии выглядит следующим образом: мужчины - 59,86 \%, женщины - 40,14\%.

Выводы. Среди пациентов с ХОЗЛ II стадии 28,67 \% больных не имели сопутствующей патологии, $27,27 \%$ - течение основного заболевания сочеталось с гипертонической болезнью II стадии, 43,36 \% ХОЗЛ сочеталось с другими заболеваниями. Анализ полученных данных по гендерному признаку указывает на преобладание у пациентов мужского пола коморбидности ХОЗЛ с другими патологиями, причем чаще всего (у 33 \% больных) с гипертонической болезнью. У лиц женского пола, больных ХОЗЛ, кроме гипертонической болезни, с высокой частотой встречалась ишемическая болезнь сердца и заболевания эндокринной системы.

КЛЮЧЕВЫЕ СЛОВА: хроническое обструктивное заболевание легких; гипертоническая болезнь; пол.

\section{PECULIARITIES OF THE COMBINED COURSE OF CHRONIC OBSTRUCTIVE PULMONARY DISEASE AND HYPERTENSION}

K.Ya. Maksiv, I.V. Pirus, R.R. Osinchuk, H.H. Habor, I.Ya. Krynytska, M.I. Marushchak

I. Horbachevsky Ternopil State Medical University

Purpose: to analyze the features of the combined course of chronic obstructive pulmonary disease of stage II and hypertension (HT) of stage II in the gender aspect.

Materials and Methods. In retrospect, 420 of patients' case histories were analyzed with the diagnosis of chronic obstructive pulmonary disease (COPD) during 2014 and 2016.

Results. Among patients with COPD, male subjects predominated (65.95\%). The gender distribution of patients with stage II COPD is as follows: male $-59.86 \%$, female $-40.14 \%$.

Conclusions. Among patients with stage II COPD $28.67 \%$ of patients had no concomitant pathology, $27.27 \%-$ COPD was combined with stage II hypertension, $43.36 \%$ - COPD combined with other diseases. The analysis of the obtained data on gender indicates the predominance in male the comorbidity of COPD with other pathologies, most often (in $33 \%$ of patients) with hypertensive disease. In female patients suffering from COPD, in addition to hypertension, there was a high incidence of coronary heart disease and endocrine system diseases.

KEY WORDS: chronic obstructive pulmonary disease; hypertension; sex.

Рукопис надійшов до редакції 31.10.2017 p.

\section{Відомості про авторів:}

Максів Христина Ярославівна - аспірант кафедри функціональної і лабораторної діагностики ДВНЗ «Тернопільський державний медичний університет імені І.Я. Горбачевського МОЗ України».

Пірус Ірина Володимирівна - студентка медичного фракультету ДВНЗ «Тернопільський державний медичний університет імені І.Я. Горбачевського МОЗ України».

Осінчук Роман Русланович - студент медичного фракультету ДВНЗ «Тернопільський державний медичний університет імені І.Я. Горбачевського МОЗ України».

Габор Галина Григорівна - доцент кафедри функціональної і лабораторної діагностики дВНЗ «Тернопільський державний медичний університет імені І.Я. Горбачевського МОЗ України».

Криницька Інна Яківна - професор кафедри функціональної і лабораторної діагностики ДВНЗ «Тернопільський державний медичний університет імені І.Я. Горбачевського МОЗ України»; тел.: +38(0352) 52-45-54.

Марущак Марія Іванівна - професор, завідувач кафредри фрункціональної і лабораторної діагностики ДВН3 «Тернопільський державний медичний університет імені І.Я. Горбачевського МОЗ України»; тел.: +38(0352) 52-45-54. 